\title{
Effect of Zirconia and Nickel Doping on the Reduction Behavior of Tungsten Oxide in Carbon Monoxide Atmosphere
}

\author{
Fairous Salleh, Tengku Shafazila Tengku Saharuddin, Alinda Samsuri, Rizafizah Othaman, and Mohd. \\ Ambar Yarmo
}

\begin{abstract}
The reduction of undoped tungsten oxide $\left(\mathrm{WO}_{3}\right)$ and doped tungsten oxide has been studied by using temperature programmed reduction (TPR) and characterized by X-ray diffraction (XRD), Brunauer-Emmett-Teller (BET) and transmission electron microscope (TEM) analysis. Zirconia $(\mathrm{Zr})$ and nickel $(\mathrm{Ni})$ doped tungsten powder were prepared by impregnation method. The effect of $\mathrm{Zr}$ and $\mathrm{Ni}$ doping on reduction of $\mathrm{WO}_{3}$ and the effect of holding time on reduction were also studied. The reduction behavior were examined by nonisothermal reduction up to $900{ }^{\circ} \mathrm{C}$ then continued with isothermal reduction at $900{ }^{\circ} \mathrm{C}$ for $45 \mathrm{~min}$ under $(40 \% \mathrm{v} / \mathrm{v})$ carbon monoxide in nitrogen $\left(\mathrm{CO}\right.$ in $\mathrm{N}_{2}$ ) atmosphere. The results show that, TPR spectra of doped powder slightly shift to a lower temperature $\left({ }^{\circ} \mathrm{C}\right)$ as compared to the undoped $\mathrm{WO}_{3}$. The reduction steps involved in the undoped $\mathrm{WO}_{3}, 10 \mathrm{~mol} \% \mathrm{Zr}$ and $10 \mathrm{~mol} \% \mathrm{Ni}$ to $\mathrm{WO}_{3}$ were found $\mathrm{WO}_{3} \rightarrow \mathrm{WO}_{2}$ and $\mathrm{W}, \mathrm{WO}_{3}$ $\rightarrow \mathrm{WO}_{2}, \mathrm{~W}$ and $\mathrm{W}_{2} \mathrm{C}$ and $\mathrm{WO}_{3} \rightarrow \mathrm{WC}$ and $\mathrm{Ni}_{0.98} \mathrm{C}_{0.02}$ respectively. The carbide formation from reduction $\mathrm{WO}_{3}$ in this study revealed that $\mathrm{WO}_{2}$ and $\mathrm{W}$ could transform to carbide in excess of $\mathrm{CO}$ introduction. The ability to enhance the reducibility involved in $\mathrm{WO}_{3}$ may associate to the presence of zirconium tungsten $\left(\mathrm{Zr}\left(\mathrm{WO}_{4}\right)_{2}\right)$ compound and nickel tungsten oxide $\left(\mathrm{NiWO}_{4}\right)$.
\end{abstract}

Index Terms - Carbon monoxide, nickel, tungsten, tungsten oxide, zirconia.

\section{INTRODUCTION}

Tungsten can form as hard steel-grey metal that is often brittle and hard to work. Among other metal in pure form, tungsten has high melting point $\left(3422{ }^{\circ} \mathrm{C}\right)$, high hardness $(3.43 \mathrm{GPa})$, high boiling point, low evaporation rate at high temperature and low thermal expansion coefficient $\left(4.5 \times 10^{-6}\right.$ $\mathrm{K}^{-1}$ ) [1]. The demand for tungsten is increasing in industries due to its good mechanical, electrical, electro erosive properties. As a results, it is the most commonly used metal for high temperature applications such as filament in light bulbs, rocket nozzles in space craft [2].

However, about $60 \%$ uses of tungsten in hard-metals

Manuscript received January 5, 2015; revised March 15, 2015. This work was financially and technically supported by Ministry of Higher Education for funding scholarship, Universiti Kebangsaan Malaysia for funding this project under research grant number BKBP-FST-K003323-2014, FRGS/2/2013/TK06/UKM/02/3, ETP-2013-066, TD-2014-024 and Centre of Research and Innovation Management (CRIM) for the instruments facilities.

The authors are with the School of Chemical Science \& Food Technology, Faculty of Science and Technology, Universiti Kebangsaan Malaysia, 43600 Bangi, Selangor, Malaysia (e-mail: fairoussalleh@gmail.com, tengkushafazila@gmail.com,_alindasamsuri@gmail.com, rizafizah@ukm.edu.my, ambar@ukm.edu.my). industry as tungsten carbide (WC). It is due to their good in hardness which close to diamond and has great abrasion, low coefficient of thermal expansion and corrosion resistance. The properties is crucial in manufacturing industry for metal, forming tools and dies, mining and abrasive tools which can be employed in high pressure, temperature, and corrosion circumstances [3], [4].

Tungsten oxides are most frequently used as starting material for producing metal tungsten powder [5] whereas, tungsten carbide synthesized by a solid-state reaction between $\mathrm{W}$ metal and $\mathrm{C}$ at $1200-2000{ }^{\circ} \mathrm{C}$ under controlled atmosphere [6].

Several of method for reduction of $\mathrm{WO}_{3}$ has widely been studied. Reduction of $\mathrm{WO}_{3}$ powders by hydrogen is one of the widely used methods to obtain metallic tungsten of high purity. Reference [7] reported that $\mathrm{WO}_{3}$ is completely reduced to metallic at $800{ }^{\circ} \mathrm{C}$ in hydrogen atmosphere via formation of intermediate phases $\mathrm{WO}_{2.72}\left(\sim 520^{\circ} \mathrm{C}\right)$ and $\mathrm{WO}_{2}$ $\left(\sim 600^{\circ} \mathrm{C}\right)$.

Moreover, carbon monoxide also can be used as a reducing agent [8] was studied the reduction of $\mathrm{WO}_{3}$ with carbon monoxide by using TGA. The intermediate phases $\mathrm{W}_{20} \mathrm{O}_{58}$, $\mathrm{W}_{18} \mathrm{O}_{49}$ and $\mathrm{WO}_{2}$ were observed in the reduction, and the final product is WC. Generally hydrogen reduction of tungsten oxide divided into two stages: (i) a low-temperature stage $\left(<777{ }^{\circ} \mathrm{C}\right)$ which can reduce $\mathrm{WO}_{3} \rightarrow \mathrm{WO}_{2}$ involving formation and reduction of three intermediate suboxide of $\left(\mathrm{WO}_{2.96}, \mathrm{WO}_{2.9}\right.$ and $\mathrm{WO}_{2.72}$, and (ii) high temperature stage (> $777^{\circ} \mathrm{C}$ ) which reduce $\mathrm{WO}_{2}$ to $\mathrm{W}^{\circ}[9]$.

Other than reducing agent, a foreign element could also influence $\mathrm{WO}_{3}$ reduction by altering the reaction sequence and/or by changing nucleation and growth [10]. Reference [11] explored the zirconia-supported tungsten oxide reduction by methane reforming. The reduction divided into three stages namely: the reduction of $\mathrm{WO}_{3}$ to $\mathrm{WO}_{2}$, reduction of $\mathrm{WO}_{2}$ to $\mathrm{W}$ and then significant methane decomposition. The optimal operating temperature range was 900 to $1000^{\circ} \mathrm{C}$ [11]. Addition of $\mathrm{ZrO}_{2}$ to $\mathrm{WO}_{3}$ can enhance their catalytic activity and stability by improving their oxygen storage capacity, reducibility, and resistance to sintering effect [12].

The reduction and carburization of $\mathrm{NiO}-\mathrm{WO}_{3}$ mixture was performed to prepare homogenous Ni-WC composite powders. Reduction of $\mathrm{WO}_{3}$ occurred at temperatures higher than $650{ }^{\circ} \mathrm{C}$. It has been reported at temperatures above 900 ${ }^{\circ} \mathrm{C}$, the carburization to $\mathrm{WC}$ take place, otherwise $\mathrm{W}_{2} \mathrm{C}$ would be the primary carbide [3].

The reduction of $\mathrm{WO}_{3}$ was investigated under $40 \% \mathrm{CO}$ in $\mathrm{N}_{2}$ as a reducing agent by using the temperature programmed 
reduction (TPR) and characterized by XRD. The objectives of this work are to enhance the reduction behavior by study the influence of different type of doping agents on reduction behavior and investigated the reduction product produced by varying holding reaction time.

\section{MATERIALS AND METHODS}

\section{A. Chemical and Raw Materials}

Powder of model (commercial) tungsten metal (IV) oxides $\mathrm{WO}_{3} \geq 99 \%$, zirconyl chloride octahydrate, $\mathrm{Cl}_{2} \mathrm{OZr} .8 \mathrm{H}_{2} \mathrm{O}$ $(98+\%)$ from Acros Organics, nickel nitrate, $\mathrm{Ni}\left(\mathrm{NO}_{3}\right)_{2} \cdot 6 \mathrm{H}_{2} \mathrm{O}$ from Merck and ethanol, $\mathrm{C}_{2} \mathrm{H}_{6} \mathrm{O}(99.5 \%)$ from Systerm ${ }^{\circledR}$ are pure and used as supplied.

\section{B. Catalyst Preparation}

Two different doped tungsten oxides: zirconia and nickel were prepared by impregnation method. The impregnation was prepared by using a zirconyl chloride octahydrate $\left(\mathrm{Cl}_{2} \mathrm{OZr} .8 \mathrm{H}_{2} \mathrm{O}\right)$ and tungsten trioxide $\left(\mathrm{WO}_{3}\right)$ powder. The amount of zirconia added was $10 \mathrm{~mol} \%$ of total metal cation. Moreover, for $10 \mathrm{~mol} \%$ of $\mathrm{Ni}-\mathrm{WO}_{3}$ was prepared by using nickel nitrate $\left(\mathrm{Ni}\left(\mathrm{NO}_{3}\right)_{2} \cdot 6 \mathrm{H}_{2} \mathrm{O}\right)$ and $\mathrm{WO}_{3}$. The compounds were dissolved in water with additional of ethanol at $60^{\circ} \mathrm{C}$ with stirring for 4 hours, producing a viscous mixture. The solution was evaporated to dryness while stirring for 4 hours, then dried at $120{ }^{\circ} \mathrm{C}$ overnight followed by calcination in air at $600^{\circ} \mathrm{C}$ for 4 hours. The calcined solid was crushed and stored in a vial.

\section{Temperature Programmed Reduction (TPR)}

Reduction of the undoped $\mathrm{WO}_{3}$, zirconia doped $\mathrm{WO}_{3}$ and nickel doped $\mathrm{WO}_{3}$ were performed by using a Micromritics Autochem 2920 Chemisorption Analyzer apparatus. The completeness of the reduction of the powder was analysed using a temperature programmed reduction (TPR) method. 5 $-7 \mathrm{mg}$ of the samples were carried out in nonisothermal mode up to $900{ }^{\circ} \mathrm{C}$ under streaming gas mixture of $40 \%$ of $\mathrm{CO}$ in $\mathrm{N}_{2}$ with a heating rate of $10{ }^{\circ} \mathrm{C} / \mathrm{min}$ with flow gas carrier rates $20 \mathrm{ml} / \mathrm{min}$. Then, the experiment continued for isothermal mode hold for 15,30 and $45 \mathrm{~min}$ at $900{ }^{\circ} \mathrm{C}$.

\section{Characterization}

XRD analysis of test samples was performed by using XRD's Bruker AXS D8 Advance type with X-ray radiation source of $\mathrm{Cu} \mathrm{K \alpha}(40 \mathrm{kV}, 40 \mathrm{~mA})$ to record the $2 \theta$ diffraction angle from $10^{\circ}$ to $80^{\circ}$ at wavelength $(\lambda=0.154 \mathrm{~nm})$ of $1 \mathrm{~g}$ sample. For identification purposes of crystalline phase composition, diffraction pattern obtained were matched with standard diffraction data (JCPDS) files.

Nitrogen adsorption at $77 \mathrm{~K}$ (liquid nitrogen) was conducted using a Micromeritics ASAP 2010 instrument to obtain the adsorption isotherm of each sample. The Brunauer-Emmett-Teller (BET) surface area, micropores volume and micropores area were also calculated from the isotherms plot. Before analyses were done, samples were degassed at $200{ }^{\circ} \mathrm{C}$ for 4 hours.

The TEM analysis was performed using a Philips CM12 transmission electron microscope with an electron gun at 200 $\mathrm{kV}$. Samples were dispersed in ethanol using supersonic waves and then placed on $\mathrm{Cu}$ grids under atmospheric condition.

\section{RESUlTS AND DISCUSSION}

\section{A. Characterization of Undoped and Doped $\mathrm{WO}_{3}$ Using $X R D$}

XRD spectra of as prepared undoped and doped $\mathrm{WO}_{3}$ obtained after calcination at $600^{\circ} \mathrm{C}$ are shown in Fig. 1. All peaks in the diffraction pattern of undoped $\mathrm{WO}_{3}$ were assigned to the stoichiometric monoclinic phase (JCPDS 1-072-0677). Addition of $10 \mathrm{~mol} \%$ of $\mathrm{Zr}$ to $\mathrm{WO}_{3}$ there is minimal change observed with respect to displays of zirconium oxide $\left(\mathrm{ZrO}_{2}\right)$ and zirconium tungsten $\left(\mathrm{Zr}\left(\mathrm{WO}_{4}\right)_{2}\right)$ phase appear, indicating in a primarily $\mathrm{WO}_{3}$ based structure. Moreover, addition of $10 \mathrm{~mol} \% \mathrm{Ni}$ there was a changes observed with respect to presence of complex oxide of nickel tungsten oxide $\left(\mathrm{NiWO}_{4}\right)$.

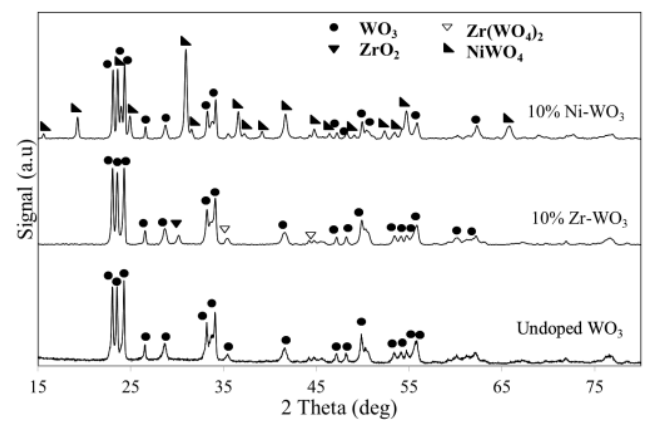

Fig. 1. XRD patterns of the fresh undoped $\mathrm{WO}_{3}, 10 \mathrm{~mol} \% \mathrm{Zr}-\mathrm{WO}_{3}$ and 10 mol\% Ni- $\mathrm{WO}_{3}$ samples obtained after calcination at $600{ }^{\circ} \mathrm{C}$ for 4 hours.

\section{B. Physical Surface Analysis (BET)}

BET surface area $\left(\mathrm{S}_{\mathrm{BET}}\right)$ of the undoped $\mathrm{WO}_{3}$ and $\mathrm{Zr}$ and $\mathrm{Ni}$ doped $\mathrm{WO}_{3}$ catalysts are summarized in TABLE I. Surface area of undoped $\mathrm{WO}_{3}$ was $2.20 \mathrm{~m}^{2} / \mathrm{g}$. While, surface area of doped tungsten oxide for $10 \mathrm{~mol} \% \mathrm{Zr}$ and $10 \mathrm{~mol} \% \mathrm{Ni}$ doped tungsten oxide were 3.75 and $3.79 \mathrm{~m}^{2} / \mathrm{g}$ respectively. It was found the surface area was increase with addition of $\mathrm{Zr}$ and $\mathrm{Ni}$ to $\mathrm{WO}_{3}$. This could suggest that has more active sites that might be attributed to the lower temperature reduction of $\mathrm{WO}_{3}$ after doping. Hence, the addition can significantly increase the surface area.

TABLE I: BET SURFACE AREAS OF PURE $\mathrm{WO}_{3}$, NiCKEL AND ZIRCONIUM

\begin{tabular}{|c|c|c|c|}
\hline Compounds & $\begin{array}{c}\text { Surface } \\
\text { area }\left(\mathbf{m}^{\mathbf{2}} / \mathbf{g}\right)\end{array}$ & $\begin{array}{c}\text { Pore } \\
\text { Size } \\
(\mathbf{n m})\end{array}$ & $\begin{array}{c}\text { Pore } \\
\text { Volume } \\
\left(\mathbf{c m}^{\mathbf{3}} / \mathbf{g}\right)\end{array}$ \\
\hline Undoped $\mathrm{WO}_{3}$ & 2.20 & 16.92 & 0.009 \\
\hline $10 \% \mathrm{Zr}-\mathrm{WO}_{3}$ & 3.75 & 12.89 & 0.012 \\
\hline $10 \% \mathrm{Ni}-\mathrm{WO}_{3}$ & 3.79 & 18.39 & 0.017 \\
\hline
\end{tabular}

Pore size of undoped $\mathrm{WO}_{3}$ was $16.92 \mathrm{~nm}$, by addition of $10 \mathrm{~mol} \% \mathrm{Zr}$ and $10 \mathrm{~mol} \% \mathrm{Ni} \mathrm{Zr}$ to $\mathrm{WO}_{3}$ were 12.89 and $18.39 \mathrm{~nm}$ respectively. It was found that the pore size increasing by addition of Ni. Moreover the pore volume for undoped was $0.009 \mathrm{~cm}^{3} / \mathrm{g}$, by addition of $\mathrm{Zr}$ and $\mathrm{Ni}$ the pore volume were increased to 0.012 and $0.017 \mathrm{~cm}^{3} / \mathrm{g}$ respectively. It could be due to more pore volume were filled with metal doping. 


\section{Surface Morphology by TEM}

TEM analysis has shown the morphology of undoped and doped $\mathrm{WO}_{3}$ shown in Fig. 2. By addition of $\mathrm{Zr}$, the structure observed seems agglomerate and not clearly differentiating with TEM. However effect of addition of $10 \mathrm{~mol} \% \mathrm{Zr}$ resulted in presence of new peaks of zirconium tungsten oxide $\left(\mathrm{Zr}\left(\mathrm{WO}_{4}\right)_{2}\right)$ and zirconium oxide $\left(\mathrm{ZrO}_{2}\right)$, whereas 10 mol\% of Ni resulted in presence of complex oxide of nickel tungsten oxide, $\mathrm{NiWO}_{4}$ which supported with XRD results shown in Fig. 1.

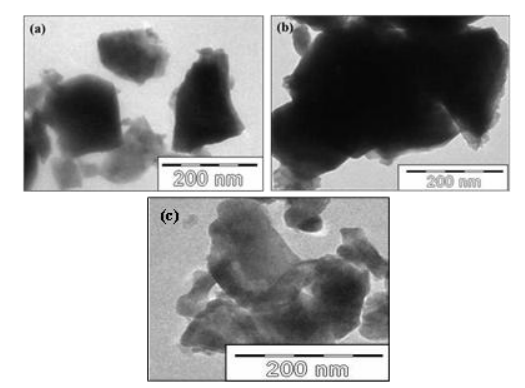

Fig. 2. TEM microstructures of (a) $\mathrm{WO}_{3}$ powder (b) $10 \mathrm{~mol} \% \mathrm{Zr}-\mathrm{WO}_{3}$ and (c) $10 \mathrm{~mol} \% \mathrm{Ni}-\mathrm{WO}_{3}$ calcined at $600{ }^{\circ} \mathrm{C}$ for 4 hours.

\section{Temperature Programmed Reduction (TPR)}

Nonisothermal TPR profiles obtained in a carbon monoxide atmosphere $\left(40 \% \mathrm{CO}\right.$ in $\left.\mathrm{N}_{2}\right)$ for the $\mathrm{WO}_{3}, 10$ $\mathrm{mol} \% \mathrm{Ni}-\mathrm{WO}_{3}$, and $10 \mathrm{~mol} \% \mathrm{Zr}-\mathrm{WO}_{3}$ were compared. The TPR profile of nonisothermal reduction until $900{ }^{\circ} \mathrm{C}$ then continued with isothermal reduction at $900{ }^{\circ} \mathrm{C}$ for $45 \mathrm{~min}$ shown in Fig. 3. Generation of carbon dioxide $\left(\mathrm{CO}_{2}\right)$ as product gas was observed and measured by TCD signal.

The TPR profile (a) of undoped $\mathrm{WO}_{3}$ is observed as a broad shoulder indicates that reduction does not commence detectably due to low rate of reaction occurred lead to low TCD signal. However, small reduction to suboxide $\mathrm{WO}_{2.9}$ of undoped $\mathrm{WO}_{3}$ begins at temperature $600{ }^{\circ} \mathrm{C}$. After holding the temperature constants at $900{ }^{\circ} \mathrm{C} \quad(78 \mathrm{~min})$ for approximately $45 \mathrm{~min}$, a new peak which denoted as I observed at $80 \mathrm{~min}$. This peak attributed to the formation of suboxide $\mathrm{W}_{18} \mathrm{O}_{49}$ (more) and $\mathrm{WO}_{2}$ (less). However reduction of $\mathrm{WO}_{2}$ thus produced might be that responsible for the following incomplete peak commencing near at holding time at 45 min. Reduction step $\mathrm{WO}_{3} \rightarrow \mathrm{WO}_{2.92}$ in undoped $\mathrm{WO}_{3}$ sample was not detected due to low signal. It is comparable to previous literature reported [9] reduction $\mathrm{WO}_{3}$ by $\left(5 \% \mathrm{H}_{2} / \mathrm{N}_{2}\right)$ which give two peaks at $696{ }^{\circ} \mathrm{C}$ and $867^{\circ} \mathrm{C}$ which represent reduction of $\mathrm{WO}_{3}$ to suboxide $\mathrm{WO}_{2.9}$ and $\mathrm{WO}_{2.9}$ to $\mathrm{WO}_{2}$ respectively.

The shoulder and peak monitored in profile (b) were denoted as I and II at approximately $40 \mathrm{~min}$ and $87 \mathrm{~min}$ respectively for $10 \mathrm{~mol} \% \mathrm{Zr}-\mathrm{WO}_{3}$. The low peak I observed at $482{ }^{\circ} \mathrm{C}$ represents to reduction of $\mathrm{WO}_{3}$ to $\mathrm{WO}_{2.92}$ in agreement with previous study which small peak arising at $600{ }^{\circ} \mathrm{C}$ which attributed to the $\mathrm{WO}_{3} \rightarrow \mathrm{WO}_{2.92}$ reduction step [13]. $\mathrm{WO}_{3}$ first reduce to $\mathrm{WO}_{2.92}$, after reached temperature $900{ }^{\circ} \mathrm{C}$, the reaction continued for $45 \mathrm{~min}$, peak detoned as II appears which represent for $\mathrm{WO}_{18} \mathrm{O}_{49}$ (less) to $\mathrm{WO}_{2}$ (more). The incomplete peak beginning near at holding time at 45 min might probably responsible for reduction of $\mathrm{WO}_{2}$ to $\mathrm{W}$. It is clearly show that addition of $\mathrm{Zr}$ to $\mathrm{WO}_{3}$ could give remarkable influence on the reduction process of the powder. TPR spectra of $\mathrm{Zr}$ doped powder had been shifted to a lower temperature, $482{ }^{\circ} \mathrm{C}$ compared to reduction of undoped $\mathrm{WO}_{3}$ that reduce to $\mathrm{WO}_{2.92}$ at temperature $600{ }^{\circ} \mathrm{C}$.

The TPR profile (c) represents $10 \mathrm{wt} \% \mathrm{Ni}-\mathrm{WO}_{3}$ assigned three reduction events (denoted I, II, and III). At early reduction time represent by event I owing to shoulder and small peak at $428^{\circ} \mathrm{C}$ which may regarding to the reduction of $\mathrm{WO}_{3}$ to $\mathrm{W}_{18} \mathrm{O}_{49}$. Event II and III were observed sharp peaks with high TCD signal compared to event I. Event II which belongs at peak $830{ }^{\circ} \mathrm{C}$ subsequent to reduction steps of $\mathrm{W}_{18} \mathrm{O}_{49}$ to partially $\mathrm{WO}_{2}$ and $\mathrm{W}$. After hold the reaction for $15 \mathrm{~min}$, new peak appeared which denoted to peak III, which is attributed to the $\mathrm{WO}_{3}$ reduce completely to $\mathrm{WO}_{2}$ and start to form tungsten carbide, WC. The TPR results obviously show that the reduction peak of $10 \mathrm{~mol} \% \mathrm{Ni}$ doped $\mathrm{WO}_{3}$ are slightly shifts to lower temperature $\left(428{ }^{\circ} \mathrm{C}\right)$ by enhance the reduction to form $\mathrm{W}_{18} \mathrm{O}_{49}$ as compared with the pure $\mathrm{WO}_{3}$. The interaction between $\mathrm{Ni}$ and $\mathrm{W}$ ions leads to this slightly decrease of the reduction temperature of $\mathrm{Ni}$ doped $\mathrm{WO}_{3}$.

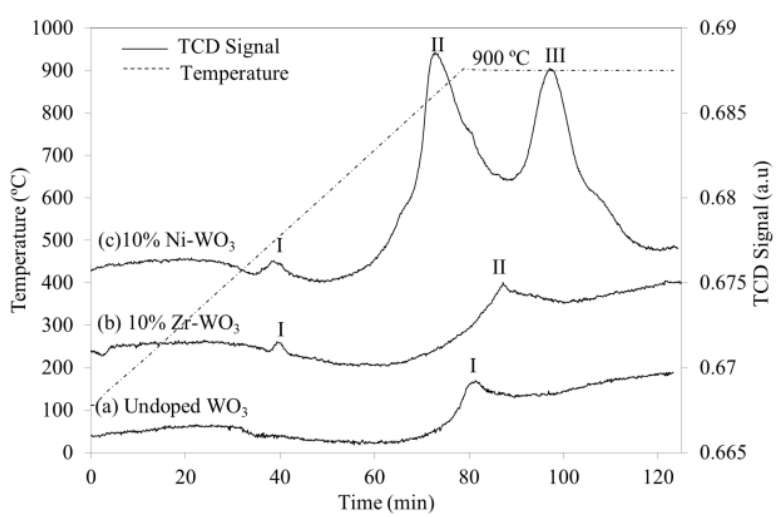

Fig. 3. TPR profile nonisothermal reduction of undoped $\mathrm{WO}_{3}, 10 \mathrm{~mol} \%$ $\mathrm{Zr}-\mathrm{WO}_{3}$ and $10 \mathrm{~mol} \% \mathrm{Ni}-\mathrm{WO}_{3}$ at temperature $900{ }^{\circ} \mathrm{C}$ and maintained for 45 min under $40 \%\left(\mathrm{CO}\right.$ in $\mathrm{N}_{2}$ ) atmosphere.

\section{E. Reduction Based on Crystallinity}

Final product of the reduction composition of doped $\mathrm{WO}_{3}$ was compared to undoped $\mathrm{WO}_{3}$. The final product was under go reduction at temperature $900{ }^{\circ} \mathrm{C}$, and maintained at different holding time as 15,30 , and $45 \mathrm{~min}$. The reduction products obtained in different holding time were collected to study the x-ray diffraction pattern of the product of reaction.

XRD analysis in sample collected after nonisothermal reduction under $40 \%\left(\mathrm{CO}\right.$ in $\left.\mathrm{N}_{2}\right)$ at $900{ }^{\circ} \mathrm{C}$ is shown in Fig 4. $\mathrm{XRD}$ analysis of reduced undoped $\mathrm{WO}_{3}$ shows formation of suboxide $\mathrm{W}_{18} \mathrm{O}_{49}$ assigned (JCPDS 01-084-1516), small amount $\mathrm{WO}_{2}$ (JCPDS 01-0871-0614), and some unreduced $\mathrm{WO}_{3}$ (JCPDS 01-075-2072). As the addition $10 \mathrm{~mol} \%$ of $\mathrm{Zr}$ to $\mathrm{WO}_{3}$, the majority of $\mathrm{WO}_{3}$ peaks reduced to suboxide $\mathrm{WO}_{18} \mathrm{O}_{49}$ and some $\mathrm{WO}_{2}$ peak observed. Peaks of $\mathrm{ZrO}_{2}$ were also detected but almost undetected. Whereas, addition of 10 mol\% $\mathrm{Ni}$, the $\mathrm{WO}_{3}$ phase were totally disappeared, but $\mathrm{WO}_{18} \mathrm{O}_{49}$ was present as the dominant species, a few peak of $\mathrm{WO}_{2}$ and new alloy peak of $\mathrm{Ni}_{4} \mathrm{~W}$ (JCPDS 03-065-2673) was detected. It was clearly can be concluded that addition of $\mathrm{Zr}$ and $\mathrm{Ni}$ enhanced the $\mathrm{WO}_{3}$ reducibility. However reduction product by addition of $\mathrm{Ni}$ shown low intensity of crystalline phase of $\mathrm{W}_{18} \mathrm{O}_{49}$ due to further reduce to $\mathrm{WO}_{2}$ in comparison 
of reduction product by addition of $\mathrm{Zr}$ which shown higher intensity.

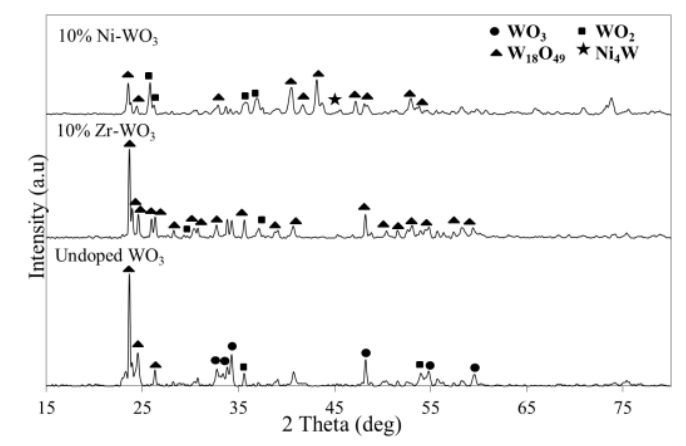

Fig. 4. XRD patterns of non-isothermal reduction of undoped $\mathrm{WO}_{3}, 10 \mathrm{~mol} \%$ $\mathrm{Zr}-\mathrm{WO}_{3}$ and $10 \mathrm{~mol} \% \mathrm{Ni}-\mathrm{WO}_{3}$ at temperature up to $900{ }^{\circ} \mathrm{C}$ under $40 \%$ (CO in $\mathrm{N}_{2}$ ) atmosphere.

Isothermal reduction was applied to further reduce the samples. The reaction was conducted at temperature $900{ }^{\circ} \mathrm{C}$ and maintained at several holding time. Fig. 5 shows the XRD patterns of isothermal reduction for $15 \mathrm{~min}$ by comparing with undoped $\mathrm{WO}_{3}, 10 \mathrm{~mol} \% \mathrm{Ni}-\mathrm{WO}_{3}$, and 10 mol\% $\mathrm{Zr}-\mathrm{WO}_{3}$. After hold for $15 \mathrm{~min}$ in reduction of undoped $\mathrm{WO}_{3}$, remaining unreduced $\mathrm{WO}_{3}$ in nonisothermal reduction was further reduce to $\mathrm{W}_{18} \mathrm{O}_{49}$, some of remaining $\mathrm{W}_{18} \mathrm{O}_{49}$ reduced to $\mathrm{WO}_{2}$ and one peak with low intensity of W (JCPDS 04-0806) were observed. Moreover, reduction of $10 \mathrm{~mol} \% \mathrm{Zr}-\mathrm{WO}_{3}$ was completely reduced to $\mathrm{WO}_{2}$ with one small peak of $\mathrm{W}_{18} \mathrm{O}_{49}$ observed by holding for $15 \mathrm{~min}$ at $900^{\circ} \mathrm{C}$. Peaks of $\mathrm{WO}_{2}$ were also observed in the XRD pattern for $10 \mathrm{~mol} \% \mathrm{Ni}-\mathrm{WO}_{3}$ as a result of further reduction for 15 min of remaining $\mathrm{WO}_{18} \mathrm{O}_{49}$. However, there a few new peaks appeared such $\mathrm{Ni}_{2} \mathrm{~W}_{4} \mathrm{C}$ (JCPDS 20-0796), $\mathrm{Ni}_{3} \mathrm{~W}_{3} \mathrm{C}$ (JCPDS 01-078-5006), Ni (JCPDS 1-077-9326), W (JCPDS 4-0806), and WC (JCPDS-051-093). After flowing with CO gas for 15 min lead to formation of tungsten carbide, WC. It is resulted from excess of $\mathrm{CO}$ supply to the samples, which converted $\mathrm{WO}_{2}$ remained in nonisothermal to WC [14].

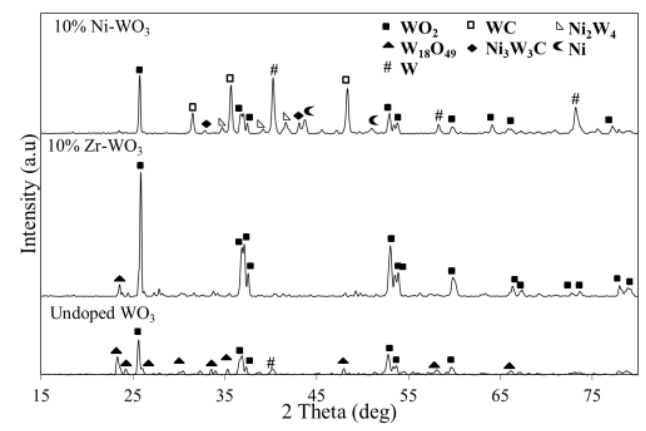

Fig. 5. XRD patterns of non-isothermal reduction of undoped $\mathrm{WO}_{3}, 10 \mathrm{~mol} \%$ $\mathrm{Zr}-\mathrm{WO}_{3}$ and $10 \mathrm{~mol} \% \mathrm{Ni}-\mathrm{WO}_{3}$ at temperature up to $900^{\circ} \mathrm{C}$ and maintained at $900^{\circ} \mathrm{C}$ for $15 \mathrm{~min}$ under $40 \%\left(\mathrm{CO}\right.$ in $\left.\mathrm{N}_{2}\right)$ atmosphere.

The reductions of samples were repeated with similar condition but increasing the holding reaction time to $30 \mathrm{~min}$. From the XRD results in Fig. 6, it is shown that undoped $\mathrm{WO}_{3}$ was further reduced by the presence of predominantly $\mathrm{W}_{18} \mathrm{O}_{49}$ phase, some $\mathrm{WO}_{2}$ and one high intensity of $\mathrm{W}$ (JCPDS 4-0806) phase observed. Furthermore, one new small peak of semi carbide, $\mathrm{W}_{2} \mathrm{C}$ (JCPDS 3-065-8829), three peaks W metal appeared from $10 \mathrm{~mol} \% \mathrm{Zr}-\mathrm{WO}_{3}$ after holding the reduction for 30 min with $\mathrm{WO}_{2}$ as a major peak. The extent of reaction to $30 \mathrm{~min}$ for $10 \mathrm{~mol} \% \mathrm{Ni}-\mathrm{WO}_{3}$, lead to disappearance of $\mathrm{WO}_{2}$ peak due to the reaction with excess CO to form high intensity of WC (JCPDS 51-0939), small peak of Ni (JCPDS 1-077-939) and W metal. Formation of phase of $\mathrm{WC}$ in reduction of $10 \mathrm{~mol} \% \mathrm{Zr}-\mathrm{WO}_{3}$ is probably due to transformation of $\mathrm{WO}_{2}$ to $\mathrm{WC}$ [7].

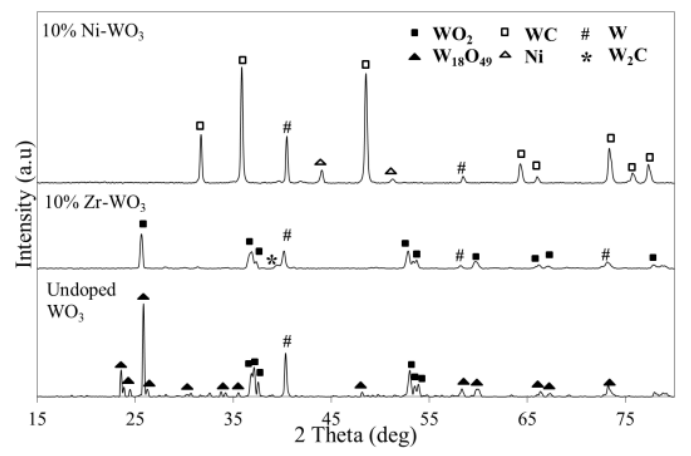

Fig. 6. XRD patterns of non-isothermal reduction of undoped $\mathrm{WO}_{3}, 10 \mathrm{wt} \%$ $\mathrm{Zr}-\mathrm{WO}_{3}$ and $10 \mathrm{wt} \% \mathrm{Ni}-\mathrm{WO}_{3}$ at temperature up to $900{ }^{\circ} \mathrm{C}$ and maintained $900^{\circ} \mathrm{C}$ for 30 min under $40 \%\left(\mathrm{CO}\right.$ in $\left.\mathrm{N}_{2}\right)$ atmosphere.

The reduction of sample was repeated with similar condition but increasing the holding reaction time to $45 \mathrm{~min}$. From the XRD results in Fig. 7, the reduction product of undoped $\mathrm{WO}_{3}$ identifying peaks predominantly $\mathrm{WO}_{2}$ phase and three peaks of $\mathrm{W}$ metal. Prolong the reduction time to 45 min of $10 \mathrm{~mol} \% \mathrm{Zr}-\mathrm{WO}_{3}$ lead to increasing the formation of $\mathrm{W}_{2} \mathrm{C}$ peaks and increasing the intensity of $\mathrm{W}$ phase instead of remaining $\mathrm{WO}_{2}$ peaks observed. Reference [3] have reported that carburization to $\mathrm{WC}$ takes place at temperatures above $900{ }^{\circ} \mathrm{C}$, otherwise $\mathrm{W}_{2} \mathrm{C}$ would be the primary carbide formed.

The XRD pattern of reduced sample of $10 \mathrm{~mol} \% \mathrm{Ni}-\mathrm{WO}_{3}$ shows the structure comprised primarily of WC, two small peaks of $\mathrm{Ni}_{0.98} \mathrm{C}_{0.02}$ (JCPDS 1-074-5561) and no $\mathrm{W}$ phase observed. The formation of WC may also transform from $\mathrm{W}$ metal, it can be seen in the reduction of $10 \mathrm{~mol} \% \mathrm{Ni}-\mathrm{WO}_{3}$ where the intensity of $\mathrm{W}$ peak decrease sharply after hold for $45 \mathrm{~min}$, compared to peak observed in reaction which hold for $30 \mathrm{~min}$. It was in agreement with previous study [8], where the formation of WC may be either from $\mathrm{WO}_{2}$ or $\mathrm{W}$.

Furthermore, additions of $\mathrm{Ni}$ to $\mathrm{WO}_{3}$ lead to a facilitated reduction and carburization which due to catalytic effect of $\mathrm{Ni}$ which enhances the $\mathrm{CO}$ adsorption [3]. However, addition of $\mathrm{Zr}$ to $\mathrm{WO}_{3}$ enhanced the reducibility by lowering the reduction temperature.

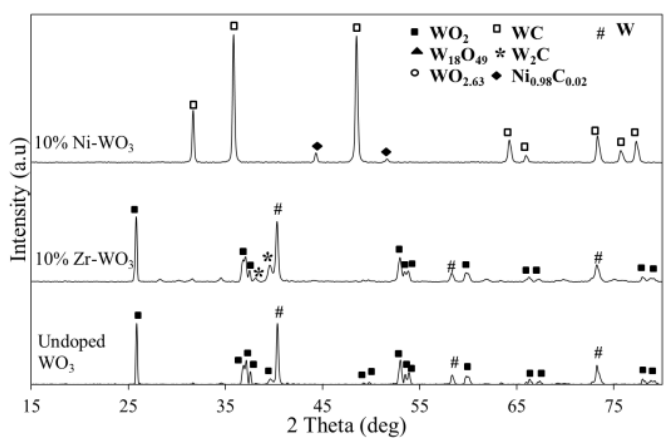

Fig. 7. XRD patterns of non-isothermal reduction of undoped $\mathrm{WO}_{3}, 10 \mathrm{~mol} \%$ $\mathrm{Zr}-\mathrm{WO}_{3}$ and $10 \mathrm{~mol} \% \mathrm{Ni}-\mathrm{WO}_{3}$ at temperature up to $900^{\circ} \mathrm{C}$ and maintained $900^{\circ} \mathrm{C}$ for 45 min under $40 \%\left(\mathrm{CO}\right.$ in $\left.\mathrm{N}_{2}\right)$ atmosphere. 
It can be concluded that, increasing the reaction time in the reduction process could improve the reducibility of the $\mathrm{WO}_{3}$ [15]. Different holding time will produce different reduction products due to different interaction with reducing agents towards changes in reduction phases. Reduction at temperature $900{ }^{\circ} \mathrm{C}$ and hold for $45 \mathrm{~min}$ in undoped $\mathrm{WO}_{3}$ and $10 \mathrm{~mol} \% \mathrm{Zr}$, were completely reduced to $\mathrm{WO}_{2}$ with low intensity of $\mathrm{W}$ metal peak. $\mathrm{W}_{2} \mathrm{C}$ also form in $10 \mathrm{~mol} \% \mathrm{Zr}$. However, by addition of $10 \% \mathrm{~mol} \mathrm{Ni}$, the $\mathrm{WO}_{3}$ was completely reduced to $\mathrm{WC}$ and $\mathrm{Ni}_{0.98} \mathrm{C}_{0.02}$.

\section{CONCLUSION}

The reduction behaviour of undoped $\mathrm{WO}_{3}$ and different doped $\mathrm{WO}_{3}$ were investigated. It can be concluded that reduction $\mathrm{WO}_{3}$ obeys the consecutive steps namely: as $\mathrm{WO}_{3}$ $\rightarrow \mathrm{WO}_{2.92} \rightarrow \mathrm{W}_{18} \mathrm{O}_{49} \rightarrow \mathrm{WO}_{2} \rightarrow \mathrm{W} \rightarrow \mathrm{W}_{2} \mathrm{C} \rightarrow$ WC. The addition of $\mathrm{Zr}$ had a remarkable influence on the reduction process of the powder by improving their oxygen storage capacity and reducibility. Furthermore, addition of $\mathrm{Ni}$ for $\mathrm{WO}_{3}$ reduction have tendency for the formation of $\mathrm{WC}$ due to the catalytic effect. Moreover by hold the reduction time could improve the reducibility of the sample oxide. The reducibility of unreduced $\mathrm{WO}_{3}$ could be enhancing by increase the concentration of $\mathrm{CO}$ or increase the holding time of reduction.

\section{ACKNOWLEDGMENT}

The author s wish to thank Ministry of Higher Education (MOHE) and Universiti Kebangsaan Malaysia (UKM) for funding this project under research grant number BKBP-FST-K003323-2014,FRGS/2/2013/TK06/UKM/02/ 3, ETP-2013-066, TD-2014-024 and Centre of Research and Innovation Management (CRIM) for the instruments facilities.

\section{REFERENCES}

[1] G. Singla, K. Singh, and O. P. Pandey, "Structural and thermal properties of in-situ reduced $\mathrm{WO}_{3}$ to $\mathrm{W}$ powder," Powder Technol., vol. 237, pp. 9-13, 2013.

[2] A. M. Baghdasaryan, O. M. Niazyan, H. L. Khachatryan, and S. L. Kharatyan, "DTA / TG study of tungsten oxide and ammonium tungstate reduction by $(\mathrm{Mg}+\mathrm{C})$ combined reducers at non-isothermal conditions," Int . J. Refract. Met. Hard Mater., vol. 43, pp. 216-221, 2014.

[3] H. Mohammadzadeh, H. Rezaie, H. Samim, M. Barati, and H. Razavizadeh, "Reduction and carburization behavior of $\mathrm{NiO}-\mathrm{WO}_{3}$ mixtures by carbon monoxide," Thermochim. Acta, vol. 590, pp. 210-218, 2014.

[4] M. R. Shabgard and A. F. Najafabadi, "The influence of dielectric media on nano-structured tungsten carbide (WC) powder synthesized by electro-discharge process," Adv. Powder Technol., vol. 25, no. 3, pp 937-945, May 2014.

[5] L. Jiqiao, H. Baiyun, and Z. Zhiqiang, "Determination of physical characterization of tungsten oxides," Int. J. Refract. Met. Hard Mater., vol. 19, no. 2, pp. 79-84, Mar. 2001.

[6] A. Hoseinpur, J. V. Khaki, and M. S. Marashi, "Mechanochemical synthesis of tungsten carbide nano particles by using $\mathrm{WO}_{3} / \mathrm{Zn} / \mathrm{C}$ powder mixture," Mater. Res. Bull., vol. 48, pp. 399-403, 2013.

[7] N. E. Fouad, K. M. E. Attyia, and M. I. Zaki, "Therrnogravimetry of $\mathrm{WO}_{3}$, reduction in hydrogen : Kinetic characterization of autocatalytic effects," Powder Technol., vol. 74, pp. 31-37, 1993.

[8] D. S. Venables and M. E. Brown, "Reduction of tungsten oxides with carbon monoxide," Thermochim. Acta, vol. 291, pp. 131-140, 1997.

[9] M. I. Zaki, N. E. Fouad, S. A. A. Mansour, and A. I. Muftah, "Temperature-programmed and X-ray diffractometry studies of hydrogen-reduction course and products of $\mathrm{WO}_{3}$ powder: Influence of reduction parameters," Thermochim. Acta, vol. 523, no. 1-2, pp. 90-96, Aug. 2011.

[10] G.-S. Kim, Y. J. Lee, D.-G. Kim, S.-T. Oh, D.-S. Kim, and Y. Do Kim "The behavior of tungsten oxides in the presence of copper during hydrogen reduction," J. Alloys Compd., vol. 419, no. 1-2, pp. 262-266, Aug. 2006.

[11] J. H. Kwak, G. Y. Han, and K. J. Yoon, "Zirconia-supported tungsten oxides for cyclic production of syngas and hydrogen by methane reforming and water splitting," Int. J. Hydrogen Energy, vol. 38, no. 20, pp. 8293-8305, Jul. 2013.

[12] L. Jiang, H. Zhu, R. Razzaq, M. Zhu, C. Li, and Z. Li, "Effect of zirconium addition on the structure and properties of $\mathrm{CuO} / \mathrm{CeO}_{2}$ catalysts for high-temperature water - gas shift in an IGCC system," Int. J. Hydrog. Energyy, vol. 37, pp. 15914-15924, 2012.

[13] A. Sim, N. W. Cant, and D. L. Trimm, "Ceria e zirconia stabilised tungsten oxides for the production of hydrogen by the methane - water redox cycle," Int. J. Hydrog. Energy 35, vol. 35, pp. 8953-8961, 2010.

[14] H. Mohammadzadeh, H. Rezaie, H. Samim, and M. Barati, "Synthesis of WC-Ni composite powders by thermochemical processing method based on co-precipitation," Mater. Chem. Phys., vol. 149-150, pp. 145-155, 2015.

[15] F. Salleh, A. Samsuri, T. S. T. Saharuddin, R. Othaman, M. Wahab, M. Hisham, and M. A. Yarmo, "Temperature-Programmed And X-Ray Diffractometry Studies Of $\mathrm{WO}_{3}$ Reduction By Carbon Monoxide," Adv. Mater. Res., vol. 1087, pp. 73-76, 2015.

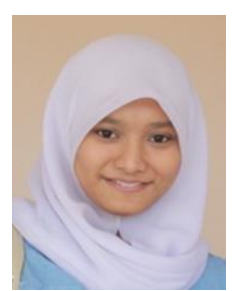

Fairous Salleh was born on May 20, 1983 in Kuantan, Pahang, Malaysia. She obtained her bachelor of science with honours in resource chemistry from Universiti Malaysia Sarawak (UNIMAS), Malaysia in 2005, and her master of science by research from Universiti Teknologi Mara Malaysia (UiTM), Malaysia in 2011.

She is currently a full time $\mathrm{PhD}$ candidate at School of Chemical Sciences and Food Technology, Faculty of Science and Technology, Universiti Kebangsaan Malaysia (UKM). She experienced working as a lecturer in Kolej Teknolgi Timur (KTT), Sepang, Malaysia for almost 2 years. Her research interests are in photocatalysis water splitting, thermocatalysis water splitting and electrolysis of water. She also interested in the catalytic gasification and pyrolysis, fuel and energy recovery from waste and waste-to-wealth.

She had won several awards including silver medal in invention, innovation and design, R\&D competition by Universiti Teknologi Mara Malaysia (UiTM) 2009.

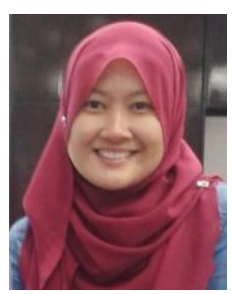

Tengku Shafazila bt Tengku Saharuddin earned his BSc in petroleum chemistry from Universiti Putra Malaysia in 2005 and MSc degree in science from Universiti Teknologi Mara, Malaysia in 2012.

She is currently a third year doctoral student at School of Chemical Science and Food Technology, Faculty of Science and Technology, Universiti Kebangsaan Malaysia (UKM). She experienced working as a chemistry lecturer at Kolej Teknologi Timur, Sepang, Malaysia for 2 years. Her research interests are in areas of water splitting for hydrogen production, renewable energy, reaction kinetics, reaction mechanisms and heterogeneous catalysts development.

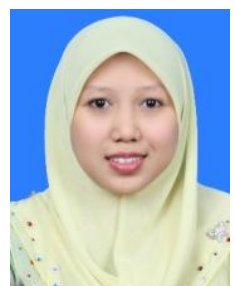

Alinda Samsuri earned her bachelor of science in analytical and environmental chemistry from Universiti Malaysia Terengganu (UMT), Malaysia in 2008 and her master of science in analytical chemistry and instrumental analysis from Universiti Malaya (UM), Malaysia in 2010.

She has been a tutor of the Centre for Defence Foundation Studies, Universiti Pertahanan Nasional Malaysia (UPNM), Malaysia since 2011. She experienced working in product development technologies in Fonterra Brands Malaysia for 2 years. She currently a PhD candidate at School of Chemical Sciences and Food Technology, Faculty of Science and Technolgy ,Universiti Kebangsaan Malaysia (UKM), Malaysia. Her research interests are in field of hydrogen production as a renewable energy by photocatalysis water splitting, thermocatalysis water splitting and electrolysis of water. She also interested in the development of homogeneous catalyst for hydrogen production application. 


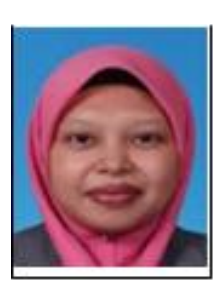

Rizafizah Othaman obtained her bachelor in chemical engineering from Tokyo Institute of Technology, Japan in 1999, master degree in chemical engineering and process from Universiti Kebangsaan Malaysia in 2004 and Doctor of engineering from Tokyo Institute of Technology, Japan in 2010.

She is currently a senior lecturer and head of the chemical technology programme at School of Chemical Sciences and Food Technology, Faculty of Science and Technolgy, Universiti Kebangsaan Malaysia (UKM). She experienced working as a chemical engineer specialized in electroless $\mathrm{NiP}$ plating with Showa Aluminium Malaysia for 2 years before being offered as chemistry lecturer at Japanese Associate Degree programme (JAD), a twinning programme for higher education between YPM Malaysia and Japan Universities Consortium. Her research interests are in the field of polymeric membrane development for renewable energy applications, wastewater treatments and gas separation, process development via catalysis and chemistry outreach and education.

Dr. Rizafizah Othaman is also a fellow member of Polymer Research Center and the Centre for Water Research and Analysis (ALIR) at UKM. She is a registered engineer with Board of Engineers Malaysia. She was awarded with Monbukagakusho Scholarship from Japanese Government during her
phD study. She had won several awards including silver medal in Brussel INOVA 2013 Competition and Bronze in PECIPTA 2013.

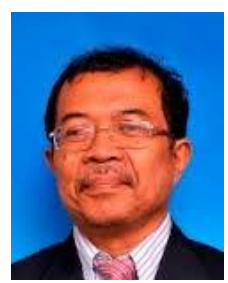

Mohd. Ambar Yarmo received his BSc in chemistry from Universiti Kebangsaan Malaysia (UKM) and his Ph.D in analytical chemistry from University Of Wales, Cardiff, U.K. He was born at Johor, Malaysia.

His research interests are in conversion of $\mathrm{CO}_{2}$ to Fuel, bio-ethanol derivatives and biofuel applications, upgrading of natural gas and palm oil to higher added value speciality chemicals using combinatorial technologies and catalysis. $\mathrm{He}$ has attended to Japanese scientific exchange programme under JSPS-VCC programme in 1988. He was a visiting scientist at Petronas Research and scientific services in 1995. He has research collaboration with Fritz Haber Institute, Max Planck Society, Berlin, Germany in 2002.

He was the outstanding UKM lecturer in research and teaching in 2000, 2002 and 2005. He is the chairman of Xapp-MNS (X-ray Application Society), Malaysian Nuclear Society. He is a senior member of International Zeolite Association (IZA, USA), Malaysian Analytical Member Society (ANALIST) and Malaysian Nuclear Society. 